\title{
Pegylated Interferon and Ribavirin Dosing Strategies to Enhance Sustained Virologic Response
}

\author{
Eric Chak $\cdot$ Sammy Saab
}

Published online: 19 June 2010

(C) The Author(s) 2010. This article is published with open access at Springerlink.com

\begin{abstract}
Hepatitis C virus (HCV) affects about 170 million people worldwide and is the most common chronic blood borne infection in the United States. Since the advent of blood screening protocols in the early 1990s, injection drug use has become the leading cause of infection. Hepatitis $\mathrm{C}$ can have both hepatic and nonhepatic manifestations of infection. Hepatic manifestations include hepatic fibrosis, cirrhosis, liver cancer, and liver failure. The standard treatment for chronic $\mathrm{HCV}$ is combination therapy with pegylated interferon- $\alpha$ and ribavirin. Although pegylated interferon and ribavirin has been used against $\mathrm{HCV}$ for close to a decade, advances in therapy have centered on doses and treatment durations. There has been increasing interest in applying on-treatment response or viral kinetics to predict antiviral response rates and shape therapeutic intervention. Protease inhibitors are a promising adjuvant to combination therapy, but their efficacy and safety are still under investigation.
\end{abstract}

Keywords Hepatitis C virus - Chronic hepatitis C. Pegylated interferon- $\alpha \cdot$ Ribavirin $\cdot$ Viral kinetics .

Protease inhibitors

E. Chak

Department of Medicine, UCLA-Oliver View Medical Center, Sylmar, CA, USA

S. Saab

Departments of Medicine and Surgery, at the David Geffen School of Medicine at University of California at Los Angeles, Los Angeles, CA, USA

\section{S. Saab $(\square)$}

Pfleger Liver Institute, UCLA Medical Center,

200 Medical Plaza, Suite 214,

Los Angeles, CA 90095, USA

e-mail: SSaab@mednet.ucla.edu

\section{Introduction}

Hepatitis C virus (HCV) infection is a worldwide public health and medical concern. About 170 million persons are infected worldwide, with an estimated 3 to 4 million Americans infected [1]. Since the advent of blood screening measures, injectable drug use has supplanted transfusionrelated $\mathrm{HCV}$ transmission as the leading cause of new infections [1]. Many individuals with chronic hepatitis $\mathrm{C}$ (CHC) are unaware of their infection and are diagnosed incidentally. Indeed, the cohort of individuals infected two or three decades ago are now seeking medical care, and presenting with advanced liver disease [2].

$\mathrm{CHC}$ can lead to hepatic fibrosis, cirrhosis, hepatocellular carcinoma, and hepatic failure. Hepatitis $\mathrm{C}$ is currently the most common indication for liver transplantation in the United States [3]. Current treatment strategies for $\mathrm{CHC}$ involve an immune modulator, pegylated interferon (peginterferon)- $\alpha$ and the antiviral drug, ribavirin. The mechanism of interferon's antiviral activity is thought to interact directly to interferon-stimulated response elements on DNA leading to translation of proteins that interfere with $\mathrm{HCV}$ replication and have immunomodulatory actions on the innate and adaptive immune systems [4]. Similarly, ribavirin is believed to work via RNA viral mutagenesis [5].

Treatment using interferon-based therapy improves patient outcomes and natural history [6,7]. The survival in one study was related to duration of antiviral therapy [8]. The predictors of antiviral response are stratified according to host, viral, and on-treatment factors [9]. Unfortunately, most of these factors are nonmodifiable. The genetic polymorphism in the interleukin (IL) $28 \mathrm{~b}$ gene can predict the likelihood of achieving a sustained virologic response (SVR). This finding highlights the important role of the human host in dealing with the viral infection. Indeed, IL- 
28B genotype is an important predictor in achieving a sustained viral response in patients with hepatitis $\mathrm{C}$ genotype 1 .

Although some guidelines have been established, duration of treatment and dosing strategies of the aforementioned drugs are still being optimized in an effort to improve the SVR. Recent studies have demonstrated increasing efficacy in extended therapy beyond 48 weeks in slow interferon responders, and the use of weight-based ribavirin. Furthermore, select patients may not require standard treatment durations.

\section{Epidemiology}

There are six HCV genotypes, which appear to vary by region of the world. In the United States and Western Europe, genotype 1 is the most common, followed by genotypes 2 and 3. Genotypes 4, 5, and 6 are generally found in Egypt, South Africa, and Southeast Asia, respectively. According to the most recent National Health and Nutrition Examination survey, the prevalence of anti$\mathrm{HCV}$ antibodies in the United States is about $1.6 \%$. The peak prevalence was seen in those ages 40 to 49 years with the strongest risk factor being injection drug use. However, the survey did not include incarcerated or homeless persons, so the true prevalence of $\mathrm{HCV}$ infection may actually be much higher than reported [10].

\section{Natural History of Infection}

Although HCV accounts for about $20 \%$ of acute hepatitis in the United States [11], it is generally not diagnosed in the acute phase because most patients are asymptomatic. Recent data has suggested that genetic polymorphisms upstream of the IL28B gene may be related to the ability to spontaneously clear the virus. Of note, patients with the $\mathrm{C} / \mathrm{C}$ genotype have been shown to have spontaneous clearance rates of $50 \%$ to $55 \%$, but those with the $\mathrm{T} / \mathrm{T}$ genotype only had clearance rates of $16 \%$ to $20 \%$ [12••]. The authors of this study note that the $\mathrm{C}$ allele is more common in people of European than African ancestry. Preliminary data suggest the genetic polymorphism may also predict treatment response in patients infected with CHC virus genotype $1[13 \bullet \bullet]$.

Of patients who are acutely infected with $\mathrm{HCV}$, the viral load can be detected as early as 1 to 3 weeks and antibodies detected between 2 and 3 months after exposure [14], and more than $90 \%$ will have anti-HCV antibodies 3 months after first exposure. Further, $54 \%$ to $86 \%$ of patients fail to clear the virus by 6 months and develop a chronic hepatitis [15]. Over time, fibrosis and then cirrhosis may develop.
Hepatocellular carcinoma (HCC) develops in about $1 \%$ to $5 \%$ of patients with $\mathrm{CHC}$ infection after 2 decades of infection [14].

\section{Indications for Treatment}

According to recent guidelines from the American Association for the Study of Liver Diseases (AASLD), any patient who is infected with HCV should be considered a candidate for treatment [16]. Specifically, the AASLD recommends treating patients with compensated liver disease (total serum bilirubin $<1.5 \mathrm{~g} / \mathrm{dL}$, International Normalized Ratio 1.5 , serum albumin $>3.4$, platelet count $75,000 \mathrm{~mm}$, and no evidence of encephalopathy or ascites). The risk and benefits of antiviral therapy need to be considered, and patients must be healthy enough to endure the treatment regimen. Patients being treated should have a liver biopsy showing evidence of chronic liver injury. Because of the high SVR rate and the short duration of treatment, the liver biopsy may be considered optional in patients with genotypes 2 and 3. Contraindications to treatment include uncontrolled major depressive illness, history of solid organ transplant (other than liver), autoimmune hepatitis, and severe concurrent medical diseases like heart failure, coronary artery disease, and chronic obstructive pulmonary disease.

\section{Treatment Strategies}

Antiviral therapy is associated with several adverse effects, and a varied likelihood of achieving long-term viral suppression. Thus, patients on therapy are assessed on a regular basis to determine treatment continuation. Therapy is discontinued in patients who do not achieve viral milestones, because antiviral therapy is no longer considered efficacious. The goal of therapy is to achieve a SVR, defined as an undetectable viral load 6 months after completing antiviral therapy.

Currently, two major milestones help predict SVR and determine continual use of antiviral therapy. First, patients must achieve an early virologic response (EVR), defined as at least a 2-log drop in the viral load 12 weeks after starting therapy [17]. If treated patients do not achieve this milestone, SVR is unlikely to be realized, and therapy should be discontinued. In the last several years, the clinical impact of an EVR has been further refined. The predictability of achieving SVR in those patients who develop complete viral suppression (complete EVR [cEVR]) is different from those who achieve a 2-log drop but detectable virus (partial EVR [pEVR]). Higher SVR are

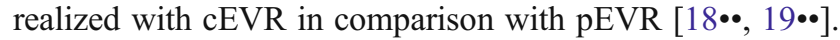


The second milestone is the viral load at week 24 of therapy. Treatment is continued only if the viral level is undetectable. Other definitions used to characterize patients' response to antiviral therapy include end-oftreatment response (EOT), defined as an undetectable viral level at the end of therapy. Figure 1 demonstrates viral milestones and definitions used during $\mathrm{HCV}$ antiviral treatment.

There has been increasing interest in another milestone, the viral load 4 weeks after starting antiviral therapy (rapid virologic response [RVR]). Patients who have an undetectable viral level at this time have an increased likelihood of achieving a SVR. In fact, the likelihood of achieving a SVR is similar: high regardless of genotype [20].

Other terms used in describing patients' response to antiviral therapy include null response (lack of 2-log drop with antiviral therapy), and partial response (2-log drop in viral load, but viral load still detectable 24 weeks after starting therapy).

\section{Currently Approved Doses for HCV Genotypes 1, 2, and 3}

The approved doses and duration of antiviral therapy are shown in Table 1. Patients infected with genotypes 1 and 4 require 48 weeks of treatment, whereas for those infected with genotypes 2 and 3, 24 weeks of treatment are believed sufficient. No large prospective study for the treatment for

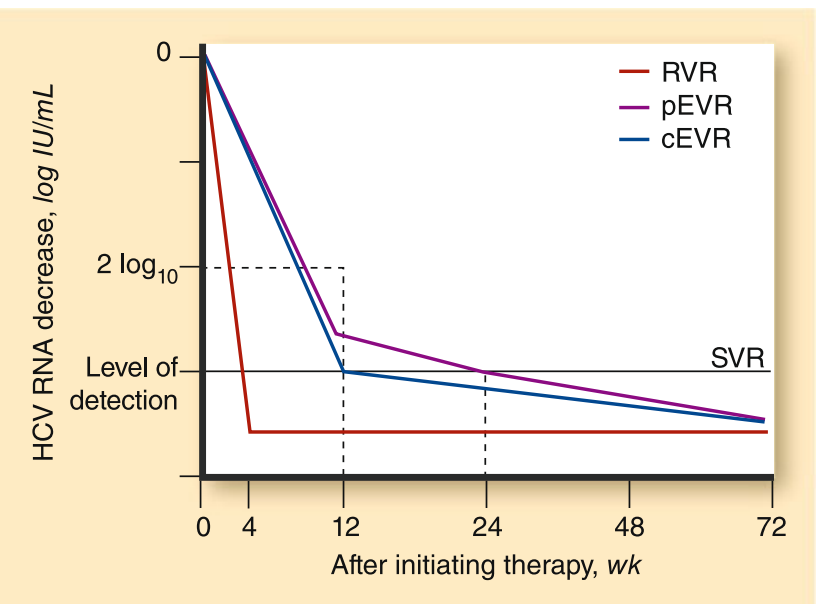

Fig. 1 Terms used to describe different responses to treatment for chronic hepatitis C virus. Rapid viral response (RVR) - undetectable viral level 4 weeks after starting antiviral therapy. Partial early viral response (pEVR), the "slow responder"- a $2 \log _{10}$ drop in viral load that is still detectable 12 weeks after starting antiviral therapy, but the viral load becomes undetectable by week 24 . Complete early viral response (cEVR) - detectable viral load at week 4, but undetectable 12 weeks after starting therapy. Sustained virologic response (SVR)viral load that is undetectable 24 weeks after completing antiviral therapy. However, if the full treatment course is only 24 weeks, as can be the case with genotype 2 and 3 patients, SVR is achieved at week 48 instead of week 72 . genotypes 5 and 6 exists, but it seems reasonable to treat these patients like genotypes 1 and 4 because they would be receiving the maximum length of combination therapy under those regimens.

\section{Weight-based Ribavirin Therapy}

Recent data from a large, multicenter, prospective trial has suggested that weight-based ribavirin $(800 \mathrm{mg}$ for patients $<65 \mathrm{~kg} ; 1000 \mathrm{mg}$ for patients $65-85 \mathrm{~kg} ; 1200 \mathrm{mg}$ for patients $>85-100 \mathrm{~kg}$; and $1400 \mathrm{mg}$ for patients $>105$ but $<125 \mathrm{~kg}$ ) is more effective than flat-dose ribavirin in patients with genotype $1(44.2 \%$ vs $40.5 \%)$, and safety profiles for each group were similar [21•*]. Other studies have also suggested weight-based ribavirin dosing may be beneficial in patients infected with genotype 2 and 3. For instance, in patients with genotype 2 and 3 , giving a lower dose of peginterferon- $\alpha-2 \mathrm{a}$ (135 $\mu \mathrm{g} / \mathrm{wk}$ compared to the standard dose of $180 \mu \mathrm{g} / \mathrm{wk}$ ) yielded high rates of SVR $(85 \%-86 \%)$ when treated with weight-based ribavirin $(11 \mathrm{mg} / \mathrm{kg}$ daily) [22••]. Other studies suggest the duration of therapy may be shortened in patients with genotype 2 and 3 infected patients treated with full-dose peginterferon$\alpha$ when weight based ribavirin is used [23••, 24, 25••].

\section{Duration of Therapy}

\section{Shortened Therapy for Genotypes 2 and 3}

Research over the past several years has focused on tailoring therapy based on the patient's virologic response to antiviral therapy. Currently, the standard duration and ribavirin dosing is 24 weeks and $800 \mathrm{mg}$ ribavirin per day. However, several studies have demonstrated that similar sustained viral response rates may be obtained in patients treated for less than 24 weeks as long as certain criteria are met: rapid viral response (RVR), weight-based ribavirin dosing, low baseline viral load, and minimal fibrosis $[23 \bullet \bullet, 24,25 \bullet \cdot$.

In one of the largest clinical trials assessing the duration of antiviral therapy in patients with genotype 2 and 3, Shiffman et al. [24] showed that there was a significant decrease in SVR when therapy was less than the approved 24 weeks as part of the multinational ACCELERATE trial. However, weight-based ribavirin dosing was not used. Recent data from the ACCELERATE investigators showed that patients with $\mathrm{HCV}$ viral load $<400,000$ who achieve RVR may be candidates for shortened therapy even while using flat-dose ribavirin [26]. Mangia et al. [23••] showed that patients treated with peginterferon- $\alpha-2 \mathrm{a}$ and weightbased ribavirin for 12 weeks had similar rates of SVR compared to those treated for the standard 24-week course 
Table 1 Standard treatment for chronic hepatitis C

\begin{tabular}{|c|c|c|c|}
\hline Genotype & Dose of peginterferon & Dose of ribavirin & Duration of treatment, $w k$ \\
\hline 1,4 & $\begin{array}{l}\text { Peginteferon- } \alpha-2 \mathrm{a}, 180 \mu \mathrm{g} \text { weekly or } \\
\text { Peginteferon- } \alpha-2 \mathrm{~b}, 1.5 \mu \mathrm{g} / \mathrm{kg} \text { weekly }\end{array}$ & $\begin{array}{l}1000 \mathrm{mg} \text { (body weight }<75 \mathrm{~kg} \text { ) or } 1200 \mathrm{mg} \\
\text { (body weight }>75 \mathrm{~kg} \text { ) daily } \\
800 \mathrm{mg} \text { (body weight }<65 \mathrm{~kg} \text { ); } 1000 \mathrm{mg} \\
\text { (body weight } 65 \text { to } 85 \mathrm{~kg} \text { ); } 1200 \mathrm{mg} \\
\text { (body weight }>85 \text { to } 100 \mathrm{~kg} \text { ); } 1400 \mathrm{mg} \\
\text { (body weight }>105 \text { but }<125 \mathrm{~kg}\end{array}$ & 48 \\
\hline 2,3 & $\begin{array}{l}\text { Peginteferon- } \alpha-2 \mathrm{a}, 180 \mu \mathrm{g} \text { weekly } \\
\text { Peginteferon- } \alpha-2 \mathrm{~b}, 1.5 \mu \mathrm{g} / \mathrm{kg} \text { weekly }\end{array}$ & $\begin{array}{l}800 \mathrm{mg} \text { daily } \\
800 \mathrm{mg} \text { daily }\end{array}$ & 24 \\
\hline
\end{tabular}

( $76 \%$ vs $77 \%$, CI-13 to 10 ). Other trials found that treating patients with peginterferon and weight-based ribavirin showed similar rates of SVR for 14 weeks [25••] and 16 weeks [27••] of treatment compared to the standard duration of 24 weeks. Predictors of response weightbased ribavirin in these trials included the absence of bridging fibrosis or cirrhosis, lower pretreatment $\mathrm{HCV}$ RNA level, and lower body weight [24]. Thus, it would be reasonable to treat genotype 2 and 3 patients possessing these favorable characteristics for 12 to 16 weeks with peginterferon- $\alpha$ and weight-based ribavirin with the expectation of similar rates of SVR compared to 24 weeks of treatment.

\section{Shortened Therapy for Genotype 1}

Similarly, in genotype 1 patients whose viral loads are undetectable after only 4 weeks of treatment (RVR), Zeuzem et al. [28] showed that patients with baseline HCV RNA $<600,000 \mathrm{IU} / \mathrm{ml}$ had an SVR rate similar to controls ( $89 \%$ vs $85 \%$ ) when treated with only 24 weeks of combination therapy. However, these studies need to be confirmed in the United States because of different demographic and, potentially, IL28B allele distribution. Thus, shortened therapy in genotype 1 patients is not recommended at this time.

Indeed, patients who achieve a RVR have a high likelihood of achieving SVR regardless of genotype [20, 24, 29•, 30]. However, likelihood of achieving an RVR does vary by genotype. Patients with genotype 1 have a $16 \%$ likelihood of achieving a RVR, compared to $60 \%$ to $70 \%$ with genotypes 2 and $3[20,24,29 \bullet, 30]$.

\section{Extended Therapy for Genotype 1}

Slow responders who achieve the milestone of a $\mathrm{pEVR}$ appear to benefit from extended therapy of 72 rather than 48 weeks. In the study by Berg et al. [19••], patients who had a pEVR had a SVR rate of $17 \%$ if they were treated for 48 weeks and $29 \%$ if treated for 72 weeks $(P=0.04)$. In addition, patients who derived the most benefit from extended therapy were those whose absolute viral level at week 24 was less than $6,000 \mathrm{IU} / \mathrm{mL}$. In a separate study by Pearlman et al. [18••], extending treatment duration from 48 weeks to 72 weeks in patients with pEVR was found to be beneficial $(38 \%$ vs $18 \%, P=0.026)$. Support for extended therapy is supported by the results of a recent Spanish study (Table 2) [31].

\section{Treatment with High-dose Peginterferon}

The use of higher than normal doses of peginterferon is currently under investigation and this may yield relevant treatment options for difficult to treat populations. One study by Buti et al. [32] randomly assigned 28 genotype 1 patients to receive three different once-weekly doses of peginterferon- $\alpha-2 \mathrm{~b}$ (3 $\mu \mathrm{g} / \mathrm{kg}$ for 1 week, $1.5 \mu \mathrm{g} / \mathrm{kg}$ for 3 weeks, and $1.0 \mu \mathrm{g} / \mathrm{kg}$ for 44 weeks). The control group of 27 patients would receive low-dose peginterferon $(0.5 \mu \mathrm{g} / \mathrm{kg}$ for 48 weeks). Both groups also received ribavirin. The

Table 2 Extended therapy for slow responders to combination therapy

\begin{tabular}{|c|c|c|c|c|c|c|}
\hline Study & Year & Patients, $\mathrm{N}$ & Treatment & $\begin{array}{l}\text { SVR after } 48 \text { weeks } \\
\text { of treatment }\end{array}$ & $\begin{array}{l}\text { SVR after } 72 \text { weeks } \\
\text { of treatment }\end{array}$ & $P$-value \\
\hline Berg et al. $[19 \bullet \bullet]$ & 2006 & 455 & $\begin{array}{l}\text { Peginterferon- } \alpha-2 \mathrm{a}, 180 \mu \mathrm{g} / \mathrm{wk} \text {, } \\
\text { and ribavirin, } 800 \mathrm{mg} / \mathrm{day}\end{array}$ & $17 \%$ & $29 \%$ & 0.04 \\
\hline $\begin{array}{l}\text { Sanchez-Tapias } \\
\text { et al. [58] }\end{array}$ & 2006 & 326 & $\begin{array}{l}\text { Peginterferon- } \alpha-2 \mathrm{a}, 180 \mu \mathrm{g} / \mathrm{wk} \text {, } \\
\text { and ribavirin, } 800 \mathrm{mg} / \text { day }\end{array}$ & $32 \%$ & $45 \%$ & 0.01 \\
\hline Pearlman et al. $[18 \bullet \bullet]$ & 2007 & 101 & $\begin{array}{l}\text { Peginterferon- } \alpha-2 \mathrm{~b}, 1.5 \mu \mathrm{g} / \mathrm{kg} / \mathrm{wk} \text {, } \\
\text { and ribavirin, } 800-1400 \mathrm{mg} / \mathrm{day}\end{array}$ & $18 \%$ & $38 \%$ & 0.026 \\
\hline
\end{tabular}


study found that in the high-dose interferon group, HCV RNA became undetectable faster and in more patients than the low interferon group [32]. In a more recent study by Roberts et al. [33], 896 genotype 1 patients were randomly assigned 1:1 to a 12-week induction therapy with highdose peginterferon- $\alpha-2 \mathrm{a}(360 \mu \mathrm{g} /$ week $)$ and 36 weeks of standard peginterferon- $\alpha-2 \mathrm{a}$ (180 $\mu \mathrm{g} /$ week) or 48 weeks of standard peginterferon- $\alpha-2 \mathrm{a}$. SVR rates were similar in the induction and control groups ( $53 \%$ vs $50 \%, P=0.29)$.

Similarly, in a large multicenter, randomized, open-label trial involving treatment naïve patients with genotypes 1 and 4 were either treated with induction peginterferon- $\alpha-2 b$ $(3.0 \mu \mathrm{g} / \mathrm{kg} / \mathrm{wk})$ for 12 weeks followed by standard dose of peginterferon-2b- $\alpha(1.5 \mu \mathrm{g} / \mathrm{kg} / \mathrm{wk})$ or standard dose of peginterferon-2b- $\alpha$ for 48 weeks. Both groups were treated with weight-based ribavirin. Overall, the SVR was $32 \%$ in the induction group versus $29 \%$ in the standard peginterferon dosing group, but the $P$-value was not significant [34]. Likewise, the PROGRESS trial was unable to find a difference between patients treated with induction doses of peginterferon$\alpha-2 \mathrm{a}(360 \mu \mathrm{g} / \mathrm{wk})$ for 12 weeks followed by standard dose peginterferon- $\alpha-2 \mathrm{a}(180 \mu \mathrm{g} / \mathrm{wk})$ for 36 weeks compared to standard dose peginterferon- $\alpha$-2a for 48 weeks ( $41 \%$ vs $43 \%$, $P$-value not reported). Both arms were treated with weightbased ribavirin. The PROGRESS trial, however, found that patients weighing $\geq 95 \mathrm{~kg}$ and those with nonalcoholic fatty liver disease activity score $\geq 3$ tended to have higher rates of SVR when treated with induction doses [35].

\section{Treatment with High-dose Ribavirin}

In a small prospective trial of 10 genotype 1 patients with high $\mathrm{HCV}$ viral loads $(>800,000 \mathrm{IU} / \mathrm{ml})$, the patients were treated with ribavirin doses to achieve a steady-state concentration of $>15 \mu \mathrm{mol} / \mathrm{L}$ in addition to standard peginterferon- $\alpha-2 \mathrm{a}$ for 48 weeks. The mean dose of ribavirin was $2540 \mathrm{mg} / \mathrm{d}$ (range 1600-3600). The study found that $90 \%$ of patients achieved SVR, but two patients required blood transfusions and all patients in the study received erythropoietin for anemia (hemoglobin $<8 \mathrm{~g} / \mathrm{dL}$ ), highlighting safety concerns associated with higher dosing of ribavirin [36]. In another trial by Shiffman et al. [37], 150 treatment-naïve genotype 1 patients treated with standard dose of peginterferon- $\alpha 2 \mathrm{~b}$, high-dose ribavirin $(1000-1600 \mathrm{mg} / \mathrm{d})$, and erythropoietin were found to have higher rates of SVR compared to patients treated with regimens containing lower doses of ribavirin (800$1400 \mathrm{mg} /$ day) $(49 \%$ vs $29 \%, P<0.05)$. Thus, it would appear that using higher doses of ribavirin than standard leads to higher rates of SVR when combined with standard dose peginterferon, but these patients will require regular screening for anemia and subsequent treatment via transfusion or erythropoiesis-stimulating agents [37].
Treatment of Nonresponders and Relapsers

About $30 \%$ of patients with $\mathrm{CHC}$ infection do not respond to peginterferon and ribavirin $[29 \bullet, 38 \bullet$. In a recent study, only $10 \%$ of patients who were initially treated with peginterferon- $\alpha-2 \mathrm{~b}(1.5 \mu \mathrm{g} / \mathrm{kg})$ and standard dose ribavirin and did not respond to treatment, achieved SVR when retreated with peginterferon- $\alpha-2 \mathrm{a}(180 \mu \mathrm{g} / \mathrm{wk})$ and ribavirin $(1000 \mathrm{mg} / \mathrm{d})$ [39]. Another study by Jensen et al. [40] found that by re-treating nonresponders with high-dose peginterferon- $\alpha-2 \mathrm{a}(360 \mu \mathrm{g} / \mathrm{wk})$ for 12 weeks followed by standard dose peginterferon- $\alpha-2$ a to complete a 72 -week course had similar SVR rates to re-treatment with peginterferon- $\alpha$ 2a $(180 \mu \mathrm{g} / \mathrm{wk})$ for 72 weeks $(16 \%$ vs $14 \%$ ), which was higher than groups treated for only 48 weeks ( $7 \%$ and $9 \%)$. All regimens included combination therapy with ribavirin. It appears then that switching the type of interferon has little effect on achieving SVR, but increasing re-treatment duration to 72 weeks may provide modest benefit. A more recent multinational study demonstrated the decision to re-treat requires consideration of degree of liver damage, genotype, and prior response to antiviral therapy [41].

The DIRECT (Daily-Dose Consensus Interferon and Ribavirin: Efficacy of Combined Therapy) trial treated 487 patients who did not respond to treatment with standard peginterferon and ribavirin were re-treated with consensus interferon and ribavirin [42]. The SVR rate using $15 \mu \mathrm{g} / \mathrm{d}$ consensus interferon and ribavirin was $10.7 \%$. Efficacy of re-treatment was associated with severity of liver damage and degree of viral response to prior therapy. For instance, the SVR in patients with at least a 2-log drop in viral levels with prior pegylated interferon and ribavirin and who did not have cirrhosis was greater than $30 \%$.

\section{Management of Adverse Reactions}

Adverse effects can lead to dose reduction and even treatment discontinuation. According to the initial trials by Fried et al. [29•] and Manns et al. [38•], adverse reactions led to the discontinuation of therapy in $10 \%$ to $14 \%$ of patients. The most common adverse reactions reported in these studies were fatigue, headache, fevers, myalgias, and injection site reactions. Major reasons for discontinuation of treatment were severe anemia, neutropenia, thrombocytopenia, and psychiatric disturbances. In the study by Manns et al. [38•], dose reduction of combination therapy for neutropenia, anemia, and thrombocytopenia, occurred in $18 \%, 13 \%$, and $3 \%$, respectively. However, discontinuation of combination therapy for neutropenia was less than $1 \%$, no patients discontinued therapy for thrombocytopenia, and discontinuation for anemia was rare. Although dose 
reduction appears to be the mainstay of adverse reaction management at this time, the use of growth factors is currently under investigation and is discussed here.

Hemolytic anemia is one of the limitations of using ribavirin. Anemia occurs between $15 \%$ to $20 \%$ of treated individuals and can lead to dose reduction or even discontinuation. Consequently, SVR can be decreased [43, 44]. Indeed, the minimal critical dose of ribavirin before SVR is compromised is likely between $60 \%$ and $80 \%$ of the expected dose [45]. In a study by Bronowicki et al. [46], 516 genotype 1 patients were treated with peginterferon- $\alpha$ 2a $(180 \mu \mathrm{g} / \mathrm{wk})$ plus ribavirin $(800 \mathrm{mg} / \mathrm{d})$. Those patients who achieved an undetectable HCV viral 2load at week 24 ( $70 \%$ of the original 516 patients) were randomized to either continuing ribavirin or receiving peginterferon monotherapy for the remaining 24 weeks. The study found that patients who stopped ribavirin had lower rates of SVR (52.8\% vs $68.2 \%, P=0.004)$, but higher quality of life scores. Hence, ensuring the complete treatment course of ribavirin is critical to the achievement of SVR [46].

Efforts to maintain ribavirin without dose modification despite anemia have included the use of erythropoietin. However, small-scale studies have failed to demonstrate that the use of erythropoietin to maintain ribavirin dose translates to better SVR [37, 47, 48]. A concern with these trials is that they are underpowered to detect a difference, if one existed. Treatment of anemia with epoetin- $\alpha$ has been shown to increase patients' quality of life $[49,50]$. In addition, there has been increased scrutiny regarding the use of epoetin- $\alpha$ for ribavirin-induced anemia because of concerns of increased mortality, thrombosis, cardiovascular events (according to the Food and Drug Administration), and the rare observation of antibody-mediated pure red cell aplasia [51]. The Food and Drug Administration has recommended against the use of epoetin- $\alpha$ in patients with hemoglobin above $10 \mathrm{~g} / \mathrm{dL}$ [52].

The role of granulocyte colony-stimulating factors (G-CSF) in the management of neutropenia induced by combination therapy has not been established. In a recent retrospective, cross-sectional study, Koskinas et al. [53] found that $\mathrm{HCV}$ patients who were given G-CSF while undergoing combination therapy had higher rates of SVR ( $32 \%$ vs $21 \%$ ), but this result was not statistically significant. Interestingly, the authors of this study found that members of the G-CSF group had higher rates of treatment adherence $(95 \%$ vs $73.1 \%, P<0.05)$. Infection was not listed as a major adverse reaction in the original trials $[28,33]$ despite not being treated with G-CSF; therefore, with the current evidence, routine use of G-CSF for the treatment of neutropenia induced by combination therapy is not recommended.

In a recent study by McHutchison et al. [54], 72 patients with HCV-related cirrhosis and thrombocytopenia (platelet counts 20,000 to $70,000 / \mathrm{cm}^{3}$ ) were randomly assigned to either receive eltrombopag, an orally active thrombopoietinreceptor agonist that stimulates thrombopoiesis, or placebo each day for 4 weeks. In this study, $95 \%$ of patients reached the goal of 100,000 platelets at the end of treatment and were able to initiate antiviral therapy for HCV [54]. The use of eltrombopag for the treatment of thrombocytopenia caused by peginterferon and ribavirin is yet to be studied, but may represent a novel approach to this adverse effect.

Major depression affects about one third of patients being treated for $\mathrm{HCV}$, and is primarily caused or exacerbated by the interferon component of combination therapy. A recent systematic review analyzed interferon- $\alpha$-induced major depressive disorder [55]. The study found that prophylactic treatment of patients with a history of depression using selective serotonin reuptake inhibitors (SSRIs) led to decreased rates of treatment discontinuation. For patients who become depressed while undergoing combination therapy, the SSRIs appear safe and efficacious, though evidence is limited at this time. Consultation with mental health professionals and use of a multidisciplinary team is advised for patients undergoing combination therapy who have a history of depression or have become depressed during treatment.

\section{Investigative Therapies}

Current response rates appear to be improved with the addition of protease inhibitors to pegylated interferon and ribavirin. For instance, in genotype 1 patients, the addition of telaprevir has been associated with an increase of SVR from $46 \%$ in patients treated with peginterferon and ribavirin for 48 weeks of treatment, to $69 \%$ in patients treated with telaprevir for 12 weeks then peginterferon and ribavirin for 24 additional weeks for 36 weeks of total treatment $(P=0.004)$ [56]. However, this study also showed that these protease inhibitors have their own set of signature adverse effects, and are associated with greater rates of discontinuation ( $21 \%$ vs $11 \%)$. Use of a different protease inhibitor, boceprevir, with peginterferon and ribavirin was also associated with greater SVR than using peginterferon and ribavirin alone ( $74 \%$ vs $38 \%$, respectively) [57]. The signature adverse effect associated with telaprevir appears to be a skin rash, and with boceprevir anemia. Treatment duration for both drugs is currently under investigation, but regimens containing boceprevir appear to range from 24 weeks to 48 weeks at present.

\section{Conclusions}

For now, the mainstay of treatment for $\mathrm{CHC}$ virus infection is peginterferon- $\alpha$ and ribavirin. Genotypes 2 and 3 are the most responsive to therapy and a 24 -week course is 
sufficient, whereas a 48 -week course is recommended for genotypes 1 and 4. Currently, too little evidence exists to recommend treatment regiments for genotypes 5 and 6 . Evidence exists to support treatment with combination therapy using weight-based ribavirin for as short as 12 weeks for patients with genotypes 2 and 3, but may need to be extended to 72 weeks for genotype 1 patients who are slower to respond to therapy.

Disclosure Sammy Saab's disclosure: a) consulting $\sim$ Genentech, b) speaker $\sim$ Merck, Genentech, Three Rivers, c) Stock Vertex, Zymogenetics; Eric Chak's disclosure - none.

Open Access This article is distributed under the terms of the Creative Commons Attribution Noncommercial License which permits any noncommercial use, distribution, and reproduction in any medium, provided the original author(s) and source are credited.

\section{References}

Papers of particular interest, published recently, have been highlighted as:

- Of importance

•- Of major importance

1. Lauer GM, Walker BD: Hepatitis C virus infection. N Engl J Med 2001, 345:41-52.

2. Alter MJ, Kruszon-Moran D, Nainan OV, et al.: The prevalence of hepatitis C virus infection in the United States, 1988 through 1994. N Engl J Med 1999, 341:556-562.

3. Verna EC, Brown RS Jr: Hepatitis C virus and liver transplantation. Clin Liver Dis 2006, 10:919-940.

4. Hoofnagle JH, Seeff LB: Peginterferon and ribavirin for chronic hepatitis C. N Engl J Med 2006, 355:2444-2451.

5. Crotty S, Maag D, Arnold JJ, et al.: The broad-spectrum antiviral ribonucleoside ribavirin is an RNA virus mutagen. Nat Med 2000, 6:1375-1379. (Published erratum appears in Nat Med 2001, 7:255.)

6. Bruno S, Stroffolini T, Colombo M, et al.; Italian Association of the Study of the Liver Disease (AISF): Sustained virological response to interferon-alpha is associated with improved outcome in HCV-related cirrhosis: a retrospective study. Hepatology 2007, 45:579-587.

7. Butt AA, Wang X, Moore CG: Effect of hepatitis C virus and its treatment on survival. Hepatology 2009, 50:387-392.

8. Wise M, Bialek S, Finelli L, et al.: Changing trends in hepatitis Crelated mortality in the United States, 1995-2004. Hepatology 2008, 47:1128-1135.

9. Ferenci P: Predictors of response to therapy for chronic hepatitis C. Semin Liver Dis 2004, 24 Suppl 2:25-31.

10. Armstrong GL, Wasley A, Simard EP, et al.: The prevalence of hepatitis C virus infection in the United States, 1999 through 2002. Ann Intern Med 2006, 144:705-714.

11. Alter MJ, Mast EE. The epidemiology of viral hepatitis in the United States. Gastroenterol Clin North Am 1994, 23:437-455.

12. •- Thomas DL, Thio CL, Martin MP, et al.: Genetic variation in IL28B and spontaneous clearance of hepatitis C virus. Nature 2009, 461:798-801. This study demonstrates that host genetic response is important in spontaneous hepatitis C viral clearance. This study demonstrates that host genetic response is important in spontaneous hepatitis $C$ viral clearance.
13. • Ge D, Fellay J, Thompson AJ, et al.: Genetic variation in IL28B predicts hepatitis C treatment-induced viral clearance. Nature 2009, 461:399-401. This study demonstrates that host genetic response is important in predicting response to antiviral therapy.

14. National Institutes of Health Consensus Development Conference Statement: Management of hepatitis C 2002 (June 10-12, 2002). Gastroenterology 2002, 123:2082-2099.

15. Seeff LB: Natural history of chronic hepatitis C. Hepatology 2002, 36(5 Suppl 1):S35-S46.

16. Ghany MG, Strader DB, Thomas DL, et al.; American Association for the Study of Liver Diseases: Diagnosis, management, and treatment of hepatitis C: an update. Hepatology 2009, 49:1335-1374.

17. Davis GL: Monitoring of viral levels during therapy of hepatitis C. Hepatology 2002, 36(5 Suppl 1):S145-S151.

18. •• Pearlman BL, Ehleben C, Saifee S: Treatment extension to 72 weeks of peginterferon and ribavirin in hepatitis c genotype 1infected slow responders. Hepatology 2007, 46:1688-1694. This trial (along with reference 19••) established extended treatment guidelines for slow responders to HCV therapy.

19. •• Berg T, von Wagner M, Nasser S, et al.: Extended treatment duration for hepatitis $\mathrm{C}$ virus type 1 : comparing 48 versus 72 weeks of peginterferon-alfa-2a plus ribavirin. Gastroenterology 2006, 130:1086-1097. This trial (along with reference 18••) established extended treatment guidelines for slow responders to HCV therapy.

20. Fried MW, Hadziyannis SJ, Shiffman ML, et al.: Rapid virologic response (RVR) is a more important predictor of sustained virologic response (SVR) than genotype in patients with chronic hepatitis $\mathrm{C}$ virus infection. Presented at European Association for the Study of the Liver. Milan, Italy; 2008.

21. •• Jacobson IM, Brown RS Jr, Freilich B, et al.: Peginterferon alfa- $2 \mathrm{~b}$ and weight-based or flat-dose ribavirin in chronic hepatitis C patients: a randomized trial. Hepatology 2007, 46:971-981. This trial (along with reference 22••) established the superiority of weight-based ribavirin over flat dose ribavirin.

22. .• Weiland O, Hollander A, Mattsson L, et al.: Lower-thanstandard dose peg-IFN alfa-2a for chronic hepatitis $\mathrm{C}$ caused by genotype 2 and 3 is sufficient when given in combination with weight-based ribavirin. J Viral Hepat 2008, 15:641-645. This trial (along with reference $21 \bullet \bullet$ ) established the superiority of weightbased ribavirin over flat dose ribavirin.

23. •• Mangia A, Santoro R, Minerva N, et al.: Peginterferon alfa-2b and ribavirin for 12 vs. 24 weeks in HCV genotype 2 or 3. N Engl J Med 2005, 352:2609-2617. This trial (along with references $25 \cdot \bullet$ and $27 \cdot \bullet$ ) established the efficacy of abbreviated therapy for genotypes 2 and 3 as long as weight-based ribavirin is used.

24. Shiffman ML, Suter F, Bacon BR, et al. Peginterferon alfa-2a and ribavirin for 16 or 24 weeks in HCV genotype 2 or 3 . N Engl J Med 2007, 357:124-134.

25. •- Dalgard O, Bjøro K, Hellum KB, et al.: Treatment with pegylated interferon and ribavarin in $\mathrm{HCV}$ infection with genotype 2 or 3 for 14 weeks: a pilot study. Hepatology 2004, 40:1260-1265. This trial (along with references 23•• and 27••) established the efficacy of abbreviated therapy for genotypes 2 and 3 as long as weight-based ribavirin is used.

26. Diago M, Shiffman ML, Bronowicki JP, et al.: Identifying hepatitis $C$ virus genotype $2 / 3$ patients who can receive a 16 -week abbreviated course of peginterferon alfa-2a (40KD) plus ribavirin. Hepatology 2010 (Epub ahead of print).

27. • Yu ML, Dai CY, Huang JF, et al.: A randomised study of peginterferon and ribavirin for 16 versus 24 weeks in patients with genotype 2 chronic hepatitis C. Gut 2007, 56:553-559. This trial (along with references 23•• and 25••) established the efficacy of abbreviated therapy for genotypes 2 and 3 as long as weightbased ribavirin is used. 
28. Zeuzem S, Buti M, Ferenci P, et al.: Efficacy of 24 weeks treatment with peginterferon alfa- $2 \mathrm{~b}$ plus ribavirin in patients with chronic hepatitis $\mathrm{C}$ infected with genotype 1 and low pretreatment viremia. J Hepatol 2006, 44:97-103.

29. • Fried MW, Shiffman ML, Reddy KR, et al.: Peginterferon alfa-2a plus ribavirin for chronic hepatitis $\mathrm{C}$ virus infection. $\mathrm{N}$ Engl J Med 2002, 347:975-982. This was one of the two original registration trials (along with reference $38 \bullet$ ) that established combination therapy with peginterferon and ribavirin as standard of care for the treatment of $\mathrm{HCV}$.

30. Hadziyannis SJ, Sette H Jr, Morgan TR, et al.; PEGASYS International Study Group: Peginterferon-alpha2a and ribavirin combination therapy in chronic hepatitis C: a randomized study of treatment duration and ribavirin dose. Ann Intern Med 2004, 140:346-355.

31. Sánchez-Tapias JM, Diago M, Escartín P, et al.; TeraViC-4 Study Group: Peginterferon-alfa2a plus ribavirin for 48 versus 72 weeks in patients with detectable hepatitis C virus RNA at week 4 of treatment [published erratum appears in Gastroenterology 2006, 131:1363]. Gastroenterology 2006, 131:451-460.

32. Buti M, Sanchez-Avila F, Lurie Y, et al.: Viral kinetics in genotype 1 chronic hepatitis $\mathrm{C}$ patients during therapy with 2 different doses of peginterferon alfa-2b plus ribavirin. Hepatology 2002, 35:930-936.

33. Roberts SK, Weltman MD, Crawford DH, et al.; Chariot Study Group: Impact of high-dose peginterferon alfa-2A on virological response rates in patients with hepatitis $\mathrm{C}$ genotype 1: a randomized controlled trial. Hepatology 2009, 50:1045-1055.

34. Brady DE, Torres DM, An JW, et al.: Induction pegylated interferon alfa- $2 \mathrm{~b}$ in combination with ribavirin in patients with genotypes 1 and 4 chronic hepatitis C: a prospective, randomized, multicenter, open-label study. Clin Gastroenterol Hepatol 2010, 8:66-71.

35. Reddy KR, Shiffman ML, Rodriguez-Torres M, et al.: Standard versus higher induction doses of peginterferon alfa-2A (40KD) and/or higher ribavirin (RBV) in HCV G1 patients with high viral load and body weight $\geq 85 \mathrm{~kg}$ : final results of the PROGRESS study [abstract]. Presented at the American Association for the Study of Liver Disease. Boston, MA; October 2009.

36. Lindahl K, Stahle L, Bruchfeld A, Schvarcz R: High-dose ribavirin in combination with standard dose peginterferon for treatment of patients with chronic hepatitis C. Hepatology 2005, 41:275-279.

37. Shiffman ML, Salvatore J, Hubbard S, et al.: Treatment of chronic hepatitis $\mathrm{C}$ virus genotype 1 with peginterferon, ribavirin, and epoetin alpha. Hepatology 2007, 46:371-379.

38. - Manns MP, McHutchison JG, Gordon SC, et al.: Peginterferon alfa- $2 b$ plus ribavirin compared with interferon alfa- $2 b$ plus ribavirin for initial treatment of chronic hepatitis $\mathrm{C}$ : a randomised trial. Lancet 2001, 358:958-965. This was the one of the two original registration trials (along with reference 29•) that established combination therapy with peginterferon and ribavirin as standard of care for the treatment of $\mathrm{HCV}$.

39. Cheruvattath R, Rosati MJ, Gautam M, et al.: Pegylated interferon and ribavirin failures: is retreatment an option? Dig Dis Sci 2007, 52:732-736.

40. Jensen DM, Marcellin P, Freilich B, et al.: Re-treatment of patients with chronic hepatitis $\mathrm{C}$ who do not respond to peginterferon-alpha2b: a randomized trial. Ann Intern Med 2009, 150:528-540.

41. Poynard T, Colombo M, Bruix J, et al.; Epic Study Group: Peginterferon alfa- $2 b$ and ribavirin: effective in patients with hepatitis $\mathrm{C}$ who failed interferon alfa/ribavirin therapy. Gastroenterology 2009, 136:1618-1628.
42. Bacon BR, Shiffman ML, Mendes F, et al.: Retreating chronic hepatitis $\mathrm{C}$ with daily interferon alfacon-1/ribavirin after nonresponse to pegylated interferon/ribavirin: DIRECT results. Hepatology 2009, 49:1838-1846.

43. McHutchison JG, Manns M, Patel K, et al.; International Hepatitis Interventional Therapy Group: Adherence to combination therapy enhances sustained response in genotype-1-infected patients with chronic hepatitis C. Gastroenterology 2002, 123:1061-1069.

44. Reddy KR, Shiffman ML, Morgan TR, et al.: Impact of ribavirin dose reductions in hepatitis $\mathrm{C}$ virus genotype 1 patients completing peginterferon alfa-2a/ribavirin treatment. Clin Gastroenterol Hepatol 2007, 5:124-129.

45. Shiffman ML, Ghany MG, Morgan TR, et al.: Impact of reducing peginterferon alfa-2a and ribavirin dose during retreatment in patients with chronic hepatitis C. Gastroenterology 2007, 132: 103-112.

46. Bronowicki JP, Ouzan D, Asselah T, et al.: Effect of ribavirin in genotype 1 patients with hepatitis $\mathrm{C}$ responding to pegylated interferon alfa-2a plus ribavirin. Gastroenterology 2006, 131: $1040-1048$.

47. Kugelmas M, Mah'moud MA: Do growth factors improve SVR in chronic HCV-genotype 1 patients treated with peg-interferon and ribavirin? AASLD Hepatology 2008 Oct 48: 4; 402A.

48. Sulkowski M, Shiffman ML, Afdhal NH, et al.: Treatment-related anemia but not epoetin use (EPO) is associated with higher SVR rates among persons treated with peginterferon (PEG)/Ribavirin (RBV): results from the IDEAL study. AASLD Hepatology 2008, 48(4): 1135A.

49. Pockros PJ, Shiffman ML, Schiff ER, et al.; PROACTIVE Study Group: Epoetin alfa improves quality of life in anemic HCVinfected patients receiving combination therapy. Hepatology 2004, 40:1450-1458.

50. Afdhal NH, Dieterich DT, Pockros PJ, et al.; Proactive Study Group: Epoetin alfa maintains ribavirin dose in $\mathrm{HCV}$-infected patients: a prospective, double-blind, randomized controlled study. Gastroenterology 2004, 126:1302-1311.

51. Stravitz RT, Chung H, Sterling RK, et al.: Antibody-mediated pure red cell aplasia due to epoetin alfa during antiviral therapy of chronic hepatitis C. Am J Gastroenterol 2005, 100:1415-1419.

52. Federal Drug Agency. Information for Healthcare Professionals: Erythropoiesis Stimulating Agents (ESA) [Aranesp (darbepoetin), Epogen (epoetin alfa), and Procrit (epoetin alfa)]. www.fda.gov/ Drugs/DrugSafety. Accessed February 8, 2009.

53. Koskinas J, Zacharakis G, Sidiropoulos J, et al.: Granulocyte colony stimulating factor in HCV genotype-1 patients who develop peg-IFN-alpha $2 b$ related severe neutropenia: a preliminary report on treatment, safety and efficacy. J Med Virol 2009, 81: 848-852.

54. McHutchison JG, Dusheiko G, Shiffman ML, et al.; TPL 102357 Study Group: Eltrombopag for thrombocytopenia in patients with cirrhosis associated with hepatitis C. N Engl J Med 2007, 357:2227-2236.

55. Sockalingam S, Abbey SE: Managing depression during hepatitis C treatment. Can J Psychiatry 2009, 54:614-625.

56. Hézode C, Forestier N, Dusheiko G, et al.; PROVE2 Study Team: Telaprevir and peginterferon with or without ribavirin for chronic HCV infection. N Engl J Med 2009, 360:1839-1850.

57. Berman K, Kwo PY: Boceprevir, an NS3 protease inhibitor of HCV. Clin Liver Dis 2009, 13:429-439.

58. Sánchez-Tapias JM, Diago M, Escartín P, et al.: Peginterferonalfa2a plus ribavirin for 48 versus 72 weeks in patients with detectable hepatitis C virus RNA at week 4 of treatment. Gastroenterology 2006, 131(2):451-460. 